\title{
Front Matter: Volume 11446
}

, "Front Matter: Volume 11446," Proc. SPIE 11446, Optical and Infrared Interferometry and Imaging VII, 1144601 (4 January 2021); doi:

10.1117/12.2591714

SPIE. Event: SPIE Astronomical Telescopes + Instrumentation, 2020, Online Only 


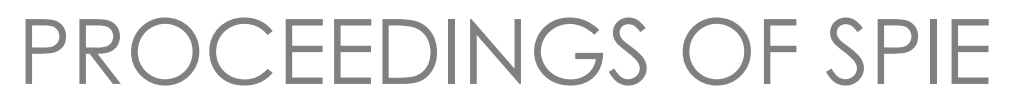

\section{Optical and Infrared Interferometry and Imaging VII}

Peter G. Tuthill

Antoine Mérand

Stephanie Sallum

Editors

14-22 December 2020

Online Only, United States

Sponsored and Published by

SPIE

Volume 11446 
The papers in this volume were part of the technical conference cited on the cover and title page. Papers were selected and subject to review by the editors and conference program committee. Some conference presentations may not be available for publication. Additional papers and presentation recordings may be available online in the SPIE Digital Library at SPIEDigitalLibrary.org.

The papers reflect the work and thoughts of the authors and are published herein as submitted. The publisher is not responsible for the validity of the information or for any outcomes resulting from reliance thereon.

Please use the following format to cite material from these proceedings:

Author(s), "Title of Paper," in Optical and Infrared Interferometry and Imaging VII, edited by Peter G. Tuthill, Antoine Mérand, Stephanie Sallum, Proceedings of SPIE Vol. 11446 (SPIE, Bellingham, WA, 2020) Seven-digit Article CID Number.

ISSN: 0277-786X

ISSN: 1996-756X (electronic)

ISBN: 9781510636798

ISBN: 9781510636804 (electronic)

Published by

SPIE

P.O. Box 10, Bellingham, Washington 98227-0010 USA

Telephone +1 3606763290 (Pacific Time) · Fax +1 3606471445

SPIE.org

Copyright (c) 2020, Society of Photo-Optical Instrumentation Engineers.

Copying of material in this book for internal or personal use, or for the internal or personal use of specific clients, beyond the fair use provisions granted by the U.S. Copyright Law is authorized by SPIE subject to payment of copying fees. The Transactional Reporting Service base fee for this volume is $\$ 21.00$ per article (or portion thereof), which should be paid directly to the Copyright Clearance Center (CCC), 222 Rosewood Drive, Danvers, MA 01923. Payment may also be made electronically through CCC Online at copyright.com. Other copying for republication, resale, advertising or promotion, or any form of systematic or multiple reproduction of any material in this book is prohibited except with permission in writing from the publisher. The CCC fee code is $0277-$ $786 \mathrm{X} / 20 / \$ 21.00$.

Printed in the United States of America by Curran Associates, Inc., under license from SPIE.

Publication of record for individual papers is online in the SPIE Digital Library.

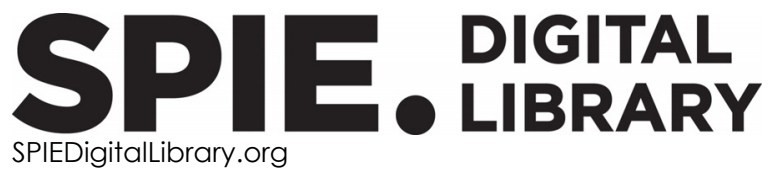

Paper Numbering: Proceedings of SPIE follow an e-First publication model. A unique citation identifier (CID) number is assigned to each article at the time of publication. Utilization of CIDs allows articles to be fully citable as soon as they are published online, and connects the same identifier to all online and print versions of the publication. SPIE uses a seven-digit CID article numbering system structured as follows:

- The first five digits correspond to the SPIE volume number.

- The last two digits indicate publication order within the volume using a Base 36 numbering system employing both numerals and letters. These two-number sets start with $00,01,02,03,04$, 05, 06, 07, 08, 09, OA, OB ... 0Z, followed by 10-1Z, 20-2Z, etc. The CID Number appears on each page of the manuscript. 


\section{Contents}

CURRENT AND PLANNED FACILITIES I

1144604 The Michelson-Pease centennial (Invited Paper) [11446-1]

1144605 Recent highlights from The CHARA Array (Invited Paper) [1 1446-2]

1144606 VLTI status update: tapping into a powerful second-generation instrumentation (Invited Paper) [11446-3]

\section{CURRENT AND PLANNED FACILITIES II}

1144607 Overview and prospects of the LBTI beyond the completed HOSTS survey (Invited Paper) [11446-4]

1144608 The Navy Precision Optical Interferometer: two years of development towards large-aperture observations (Invited Paper) [11446-5]

$1144609 \quad$ Setting the stage for first fringes with the Magdalena Ridge Observatory Interferometer (Invited Paper) [11446-6]

11446 OA An overview of the VERITAS stellar intensity interferometer [11446-7]

\section{SCIENCE HIGHLIGHT SHOWCASE I}

11446 OB Stellar surface imaging (Invited Paper) [1 1446-8]

11446 OD VLTI images of circumbinary disks around evolved stars [11446-11]

INSTRUMENTS AND SUBSYSTEMS I

$11446 \mathrm{OH} \quad$ A new frontier for J-band interferometry: dual-band NIR interferometry with MIRC-X [1 1446-15]

INSTRUMENTS AND SUBSYSTEMS II

11446 0J Testing P-REx on VLTI data [1 1446-17] 
11446 OK K-band integrated optics beam combiners for CHARA fabricated by ultrafast laser inscription [11446-18]

$11446 \mathrm{OL}$ Commissioning MATISSE: operation and performances [11446-19]

\section{SCIENCE HIGHLIGHT SHOWCASE II}

11446 ON CHARA/MIRC-X: a high-sensitive six telescope interferometric imager concept, commissioning and early science (Invited Paper) [11446-20]

1144600 The ExOGRAVITY project: using single mode interferometry to characterize exoplanets (Invited Paper) [11446-21]

11446 OP Star and planet formation with the new generation VLTI and CHARA beam combiners (Invited Paper) [11446-22]

11446 OR MIRC-X polarinterferometry at CHARA [1 1446-24]

INSTRUMENTS AND SUBSYSTEMS III

11446 OT Progress of the CHARA/SPICA project [1 1446-26]

11446 OU Development progress of the prototype long baseline optical interferometer in China [11446-27]

11446 OV First laboratory results from FOURIER, the initial science combiner at the MROI [11446-28]

FUTURE INSTRUMENTS I

1144610 MACH II: Mach-Zehnder analog correlator for heterodyne infrared interferometry [11446-61]

FUTURE INSTRUMENTS II

1144611 The James Webb Space Telescope aperture masking interferometer (Invited Paper) [11446-62]

1144613 V8: an 8 beam mid-infrared heterodyne instrument concept for the VLTI [11446-64]

TECHNOLOGIES AND LINKAGES I

1144616 Starlight on a chip: astrophotonic technologies for interferometry (Invited Paper) [11446-68]

iv 
1144617 Quantum-assisted optical interferometers: instrument requirements [11446-69]

1144618 Towards the development of mid-infrared integrated optics in the renewed context of highcontrast interferometry [1 1446-70]

1144619 Detecting and characterizing close-in exoplanets with vortex fiber nulling [11446-71]

\section{TECHNOLOGIES AND LINKAGES II}

11446 1A Long-baseline space interferometry for astrophysics: a forward look at scientific potential and remaining technical challenges (Invited Paper) [11446-89]

11446 1B Looking into the future of interferometry using free-space beam propagation [1 1446-90]

11446 1C Intensity interferometry with MAGIC [11446-91]

11446 1D First on-sky results with an interferometric discrete beam combiner (DBC) at the William Herschel Telescope [11446-92]

TECHNIQUES I

$114461 \mathrm{H} \quad$ Recovering polarized intensity distribution at diffraction limited resolution using differential speckle polarimetry [11446-96]

TECHNIQUES II

$114461 \mathrm{~J} \quad$ Review and scientific prospects of high-contrast optical stellar interferometry (Invited Paper) [1 1446-98]

$114461 \mathrm{~K} \quad$ Observing inside the coronagraphic regime with nulling interferometry [11446-99]

$114461 \mathrm{M}$ Toward an imaging capability with the Southern Connecticut Stellar Interferometer [11446-112]

\section{TECHNIQUES III}

$114461 \mathrm{~N} \quad$ Inference in optical interferometry: a quick review of modeling and imaging techniques (Invited Paper) [11446-101]

1144610 Compressed sensing for infrared interferometric imaging [1 1446-102] 
$114461 Q \quad$ Reconciling kernel-phase and coronagraphy: new steps towards combining the performance of opposing techniques [11446-104]

\section{TECHNOLOGIES \& LINKAGES III}

11446 IR Achromatic electro-optic modulation using cascaded lithium niobate Ti:diffused waveguides @670nm [11446-105]

$114461 \mathrm{~N} \quad$ Neural network based image reconstruction with astrophysical priors [1 1446-110]

POSTER SESSION: INSTRUMENTS AND SUBSYSTEMS

1144622 CHARA array adaptive optics: complex operational software and performance [11446-47]

1144623 Laboratory characterization of FIRSTV2 photonic chip for the study of substellar companions [1 1446-48]

1144626 Recent results on electro-optic visible multi-telescope beam combiner for next generation FIRST/SUBARU instruments: hybrid and passive devices [1 1446-51]

1144628 Deployment of beam alignment hardware at the Magdalena Ridge Observatory Interferometer [1 1446-53]

1144629 FIRST, a pupil-remapping fiber interferometer at the Subaru Telescope: on-sky results [1 1446-54]

11446 2A The optomechanical design of the Quad-camera Wavefront-sensing Six-channel Speckle Interferometer (QWSSI) [1 1446-55]

POSTER SESSION: FUTURE INSTRUMENTS

$114462 \mathrm{~F} \quad$ Compact unambiguous differential path-length metrology with dispersed Fabry-Perot laser diodes for a space interferometer array [1 1446-33]

$114462 G \quad$ Performance study of interferometric small-sats to detect exoplanets: updated exoplanet yield and application to nearby exoplanets [11446-34]

$114462 \mathrm{~K} \quad$ Optimast structurally connected interferometry enabled by in-space robotic manufacturing and assembly [1 1446-38]

$114462 \mathrm{~N} \quad$ Preparatory studies for a mid-infrared nulling interferometry experiment at cryogenic conditions [11446-111]

1144620 Towards ultra-broadband heterodyne interferometry in the N- and Q-bands [11446-66] 


\section{POSTER SESSION: TECHNOLOGIES AND LINKAGES}

$114462 \mathrm{P} \quad$ High temporal-spatial resolution spaceborne stellar intensity interferometry array [11446-78]

$114462 Q \quad$ Shaping apertures and masking [11446-79]

11446 2T Laser written 3D 3T spectro-interferometer: study and optimisation of the laser-written nano-antenna [1 1446-82]

$114462 \mathrm{U} \quad$ Single mode fiber coupling tip tilt control for a small amateur telescope [11446-83]

$114462 \mathrm{~V} \quad$ Active phase change for a kernel nulling interferometer [1 1446-84]

$114462 \mathrm{~W}$ On the quantum-limit of the noise temperature in balanced correlation receivers [11446-85]

$114462 Y \quad$ Digital micromirror device enabled integral field spectroscopy with the Hadamard transform technique [1 1446-87] 
Proc. of SPIE Vol. 11446 1144601-8 Downloaded From: https://www.spiedigitallibrary.org/conference-proceedings-of-spie on 26 Apr 2023
Terms of Use: https://www.spiedigitallibrary.org/terms-of-use 